\title{
ASSESSMENT OF COMPETITION IN THE BANKING SECTOR OF LITHUANIA
}

\author{
Sandra Rimavičiūtè ${ }^{1}$, Mantas Vilys ${ }^{2}$ \\ Vilnius Gediminas Technical University \\ E-mails:1'rimaviciute.s@gmail.com;'2mantas.vilys@vgtu.lt
}

\begin{abstract}
Competition in the banking sector is different from the competition in the other sectors. Banks can compete only on the basis of banking products. Also, banks are dependent on each other - actions of every market participant may strongly affect the others. Problems of one bank may encourage distrust of the entire banking system. Analysis of Lithuanian banking sector has showed that country's banking sector can be divided into three groups - the biggest banks, smaller and medium-sized banks and foreign banks branches. The largest part of banking sector is concentrated in activity of the three banks. All these banks are owned by Scandinavian capital. Lithuanian banking sector is highly concentrated. In 2005-2012 years the average mean of three banks concentration index (CR3) in deposits, assets and loans markets was 68 percent. According to these high values of concentration rates, Lithuanian banking sector can be characterized as oligopoly.
\end{abstract}

Keywords: competition, banking sector, concentration, "k" index, Hirschman (HHI) index.

\section{Introduction}

The banking system in the country's economy is undeniable. None of the modern economy nowadays functions properly without banks. Banking activities have a material impact on the financial sector and the general economy of the country, and that's why banking sector and the processes taking place in it has special attention. In recent decades, the banking sector has seen many changes. The processes of globalization, various barriers, fall in restrictions by the financial development took place in the banking consolidation. The banking sector resulted in many innovations, new financial products, which led to the development of particular new technologies in the field of finance. However, not only the mentioned processes have affected the sector in recent years. The banking sector as well as the entire financial system was shaken by the global financial crisis (2008), the effects of which were felt in all banking activities. The developments also had an impact on bank competition and banking sector concentration.

Competition assessment, researching banking sector is useful, because competition leads to sector performance, and efficient banking sector contributes to sustainable global economic growth. Lithuanian researchers haven't analyzed the research problem of banks competition and concentration much (Deltuvaite 2007; Staroselskaja 2013). Much more information about the banking competition comes from foreign authors - Strahan (2002), Claessens and Leaven (2005), Casu, Girardone (2006), Weill (2011) Strahan (2002), Bikker $(2007,2009)$ and others.
Researchers observed different approach both in the evaluation of competition through theoretical aspect and in the empirical studies.

Purpose of this article is to determine the degree of competition. The first paragraph analyzes the main theoretical approaches describing the concept of competition. First part of the article explains relationships between competition and efficiency, financial stability and access to services, as well as identifies the key factors affecting competition in the banking sector. Second part of the article discusses the methods used in the study - the three indices were used to assess the extent of competition in the banking sector. The third section analyzes the Lithuanian banking sector, assesses the degree of competition in the sector.

\section{Theoretical and empirical aspects of competition in banking sector}

Competition [Lat. Concurrent $<$ concurro - I'm running together] is derived from Latin and refers to the object's ability to compete in a changing environment. Competition in economic theory plays an important role. Interpretation of the importance of competition in the same economic science is characterized by the fact that economic theory provides scientific analytical nature. Competition in economic theory occurs not only in theory, or in various theoretical models, but is implemented in practice in competition policy also. 
In theory there is no single explanation of what is competition. The pioneer of English classical political economic school Adam Smith summed up in his work thoughts about competition of the early thinkers. Classical political economic school pioneers kept competition as a major force in the functioning of market, which forms a spontaneous and productive social order, which controls commodity prices, wage levels, techniques selection, resource allocation, business organization forms, income size. Producers compete to make profit, and its possible for consumers to expect higher quality, better than the competitor's product offerings, improved production methods or the application of new technologies (Klimašauskienè 2007). Adam Smith explained influence of competition on prices with the following example: if the amount of capital that meets the food demand in a given area is sufficient and divided between two sales areas, the competition between them shall induce to sell at lower prices than at those which would exist in the case of only one sales area. So A. Smith and other classical political economic school representatives acknowledged that the competition is more effective when it operates within the larger number of competitors (McNulty 1968).

Several defining features of the competition can be distinguished:

- Competition is related to the firms' ability to influence prices. When a company has no power to affect prices, perfect competition exists. Competition in the long term is greater than in the short, because it is more likely that new entrants - competitors will emerge in the long term.

- It is likely that strong competition is positively correlated with the number of competitors and similar size of competitors and particularly the smaller part of production goes to the largest company, the more likely that the market will be more competitive (Stigler 1972).

However, competition in the banking sector differs from competition in the other sectors. Competition in the banking sector also stands out in that it is significant for the economy of the country. For this reason, special attention and maintenance is given for competition in banking sectors. Banking competition is based solely on banking products, so it is more intense than competition in other sectors (Staroselskaja 2013). It is also important to mention the fact that the banks are interdependent. One player's action may have a significant impact on other market actors. If one system of the bank faces difficulties, distrust may arise in the whole banking system. Therefore, in the banking competition it is very important to maintain customer's confidence.

\section{Competition factors}

Bikker (2009) identified a number of factors that can influence interpretation of competition in the banking sector (Table 1).

Market structure variables are considered to be key factors influencing banking sector competition. Concentration ratio. In this classification, the main indicator of the concentration is concentration ratio (CR5) of five major banks, which refers to the five largest banks by assets, market share. As an alternative HHI index is used very widely also. Number of banks. Number of banks is used not only as a variable associated with the concentration ratio, but also as an independent variable that describes the structure of the market. Foreign-owned banks. This indicator shows foreign-owned banks in the banking system of the country when the foreign owned banks is 50 percent or more. Take into account the fact that foreign-owned banks may behave differently than domestic banks.

Table 1. Competition factors (compiled by Bikker 2007)

\begin{tabular}{|l|l|}
\hline $\begin{array}{l}\text { Market structure } \\
\text { variables }\end{array}$ & $\begin{array}{l}\text { The banking concentration ratio; } \\
\text { The number of banks; } \\
\text { Foreign-owned banks. }\end{array}$ \\
\hline $\begin{array}{l}\text { Competitiveness } \\
\text { variable }\end{array}$ & $\begin{array}{l}\text { Restrictions on activities of the sector; } \\
\text { Foreign investment restrictions. }\end{array}$ \\
\hline $\begin{array}{l}\text { Interbranch } \\
\text { competition }\end{array}$ & $\begin{array}{l}\text { Capital markets; } \\
\text { Insurance companies. }\end{array}$ \\
\hline 3 indices & $\begin{array}{l}\text { Property rights index; } \\
\text { Regulatory Code; } \\
\text { Banking liberty. }\end{array}$ \\
\hline $\begin{array}{l}\text { Macroeconomic } \\
\text { conditions }\end{array}$ & $\begin{array}{l}\text { GDP per capita; } \\
\text { Real annual GDP growth; } \\
\text { Inflation. }\end{array}$ \\
\hline
\end{tabular}

\section{Data and methods used}

To set the level of competition in the market is difficult. The literature distinguishes many models that can be used for fixing the level of competition, but they are not developed very much. In this article, the competition assessment is made by Lerner index.

Lerner index. Lerner index is a direct measure of competition, as it is focused on pricing power, given the differences between price and marginal cost, which acquired a certain degree to which a company can increase its prices in the limit of cost. Index indicates how much bank charges are higher than marginal costs. The index measures the competition, but the Lerner index is described as an index of monopoly power as well. 
Lerner index is calculated by the following formula:

$$
L=(\text { Pit }- \text { MCit }) / \text { Pit } \text {. }
$$

Pit - average bank and product price set at time $t$. MCit - bank's marginal cost.

Index value describes the competitive situation in the a market:

- In case of perfect competition (with high elasticity of demand), the index value will be close to zero.

- In the real monopoly (elasticity of demand is zero or close to zero), index value will converge to infinity.

- Between these two extremes of market structures, demand moves in the opposite direction than the monopolistic market demand and thus result in the intermediate competition situation (Kammoun, Ammar 2012).

To identify competition in the banking sector and assess it in the article " $\mathrm{k}$ " concentration index and the Herfindahl-Hirschman index are calculated.

Bank " $k$ " concentration index. Using the " $\mathrm{k}$ " concentration index, index is calculated by the largest companies in terms of market share. CR3 and CR5 concentration indices are used often. The first calculates the ratio of the three largest banks operating in the country-specific banking system market share. The second indicator is calculated by analogy with the five largest banks' market share.

" $\mathrm{K}$ " concentration index is calculated by the formula (Bikker, Haaf 2000):

$$
C R n=\sum k i=1 \text { si. }
$$

Formula values: $k$ - Number of banks, $s i$ - bank's share in the market. From 0 percent up to 35 percent - market is characterized by low concentrations. Since 35 percent up to 70 percent - market is characterized by medium levels. Since 70 percent up to 100 percent - market is characterized by high concentration level.

Herfindahl-Hirschman Index (HHI). This index is widely used in literature for the concentration ratio, which is often used as another measure of the concentration of Valuation index. HHI index is calculated as the Bank of values in terms of market share, the sum of squares. The $\mathrm{HHI}$ is calculated by the following formula:

$$
H H I=\sum n i=1 s 2 i .
$$

When HHI $<1000$, degree of market concentration is low. When $1000<\mathrm{HHI}<1800$, market concentration ratio is average. When $\mathrm{HHI}>1800$, the degree of market concentration is high.

\section{Competition in the banking sector assessment Lithuanian banking sector analysis}

Lithuania's banks own 81 percent of the whole financial system assets. Currently, Lithuania has seven licensed banks, nine foreign bank branches, two foreign bank representative offices and 269 EU banks operating in the Republic of Lithuania without establishing a mission (Lietuvos bankas 2012). Recent years for Lithuanian banking sector was exceptional and brought significant changes. Fifth largest bank collapsed after a decade without any major shocks in its activities. In the end of 2011 AB SNORAS activities were suspended. The banking system has withstood bank's suspension of activities and has remained stable, but it affected the structure of sector, which decreased. AB Snoras assets amounted to 8.1 billion euros, deposits amounted to 5.9 billion euros, loans -3.6 billion Lt. In these volumes size of the banking sector decreased. AB Snoras customers had to choose another bank so in this case major banks experienced benefits.

Before the collapse of AB Snoras, Lithuania's banking sector had nine Lithuanian banks holding a banking license. As already mentioned, this year there are seven such banks. In the beginning of 2013 AB Ūkio bankas banking license was canceled. The Bank of Lithuania suspended it on the initiative, whereas the bank supervision was to determine the bank's failings and regulatory violations. In the case of Ükio bankas the purpose was to preserve the continuity of bank activities, searching for banks which would want to participate in the restructurisation of the liquidated bank and in the transfering of liabilities of Ūkio bankas. Ūkio bankas assets and liabilities were transferred to Šiaulių bankas (Lietuvos bankas 2013).

Lithuanian banking sector, in accordance with its existing banks size, can be divided into three groups. The major banks may be attributed to the first group, medium and smaller banks may be attributed to the second group, and the foreign bank branches and subsidiaries - to the third group (Staroselskaja 2013).

Three major commercial banks, holding leadership positions in Lithuanian banking sector, belong to the first group. These banks are distinguished by wide circle of clients: services to private individuals and businesses, working with large businesses. Major commercial banks provide variety of services. Three largest banks operating in the country currently cover Lithuanian banking sector among the major commercial banks: SEB bank, Swedbank AB and AB DNB bank. All three of the main and the biggest banking sector banks are holding Scandinavian capital. 
Medium-sized and small banks have lower diversity of services offered, and smaller circle of clients. All the banks, which may be attributed to this group of smallerbanks, in carrying out their activities are geared to develop partnerships with small and medium-sized enterprises. Customers may be individuals, micro, small and medium-sized enterprises. AB Šiaulių bankas, UAB Medicinos bankas, AB FINASTA and Citadelè may be attributed to Lithuanian banking sector of medium and smaller banks. This group represents four banks. Third group consists of branches of foreign banks and branches of foreign banks operating in Lithuania. These banks hold the smallest share of the market and are engaged in traditional banking services, provide loans, deposits and other repayable funds engaged in activities related to investment management. Also, many foreign bank branches are concentrated in the business of customer service, perform operations with international companies. Lithuanian foreign bank branches, departments - Danske bank, Nordea bank, BIGBANK branch bank Pohjola and others.

Number of banks. In the beginning of creation of banking sector in Lithuania number of banks was rapidly increasing. At that time, economic conditions were very favorable to the banking establishment. Banking business has been particularly attractive, promising large profits, enough customers, as well as the "input" on the market has been fairly liberal (Ramon 2002). In 1993 Lithuania had twenty-eight commercial banks. This is the maximum number of banks in the Lithuanian banking history. Until 1996 number of banks has decreased by almost three times. Banks faced serious problems because of lack of experience, competence, as well as the lack of supervision in banking sector. Banks have started to disappear one after another. Decreased number of commercial banks no longer reaches similar volumes. Lithuania currently has seven commercial banks and nine foreign bank branches (Fig. 1).
Banks are in competition with each other, trying to meet user needs and expectations. Banks can compete on their own offers' exclusivity and diversity, but considering Lithuanian market large gap between lower and big banks show differences in their competitiveness. Smaller banks can hardly compete with the major. Big banks cannot afford to provide all possible services. Lithuanian big Scandinavian capital commercial banks have significantly greater financial resources. Banks' size makes them more attractive not only because of greater financial opportunities, but perhaps for security reasons. In theoretical part one of the possible approaches about big banks was mentioned. These banks can be considered more secure due to their size, users may argue that large banks are less risky, and there is less chance that these banks will face serious problems (Too -big -to- fail). This approach is rather subjective, but it is likely that it can also be one of the reasons contributing to the fact that large banks attract a greater number of customers.

Infrastructure. When assessing the competition in the banking sector it is possible to consider the infrastructure-related data also. Banks location in the country, their availability is also an important banking service to consumers.

Lithuanian banking sector is fairly well developed, total sum of bank branches operating in the sector is high and their availability can be measured at high level. In 2010 hundreds of thousands of adults in Lithuania went to 27 banks. Similar number of bank branches sustaining hundreds of thousands of adult population was in Latvia 31, and to a lesser extent in Estonia - 19. Lithuania has highly developed banking sector compared to such countries as United Kingdom (26), Germany (18) (World Bank database).

Banks are also competing in payment cards. Payment transactions with debit and credit cards include payments

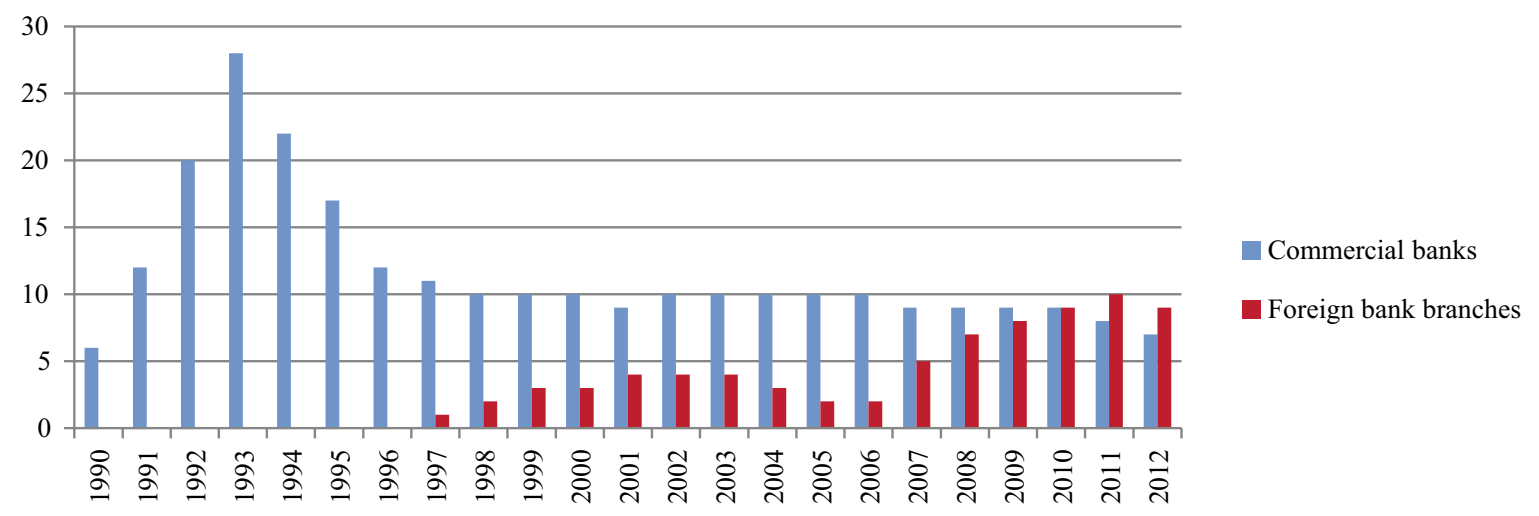

Fig. 1. Number of commercial and foreign bank branches in Lithuania (1990-2012)

(Source: Created by authors, according to Lithuanian Bank Credit Institution Review) 
in card readers and in electronic stores. Banks earn from legal and natural persons who have debit or credit cards. Also, banks earn income from merchants for card services. In 2011 Lithuania made 100.4 million local transfers by debit and credit cards. All of these transfers amounted to 5.3 billion LTL (Lietuvos bankas 2011). Bank card industry in 2011 earned a total of 181.2 million LTL. Largest part of income was earned by banks from merchants for card services - 181.2 million LTL. Banking revenue from credit cards amounted to 70.9 million LTL, and income from debit cards to 32.4 million LTL.

Number of payment cards in 2010-2011 in Lithuania fell by 8.8 percent. The main reason for this decline has been halted AB Snoras bank activities (Lietuvos bankas 2012). In the end of 2012 Lithuanian banks had released 3.7 million payment cards. Over the years, this number has increased by 73.459 thousand (Lietuvos bankų asociacija 2012). Half of the payment card market belongs to one of the largest banks Swedbank taking the 50 percent card market. In 2012 it issued nearly 1.9 million cards. Another third of the cards are issued by other one of the largest banks - SEB bank. SEB bank card number amounts to 985544 cards, so 80 percent of the market cards consist of two banks (SEB bank and Swedbank). The only Medicinos bank does not allow its customers to use payment cards.

\section{Concentration in Lithuania banking sector}

For the assessment of concentration in Lithuanian banking sector Herfindahl-HirschmanIndex (HHI) was used. HHI index shows that Lithuaniais subjected to high level concentration. When the index value exceeds 1800 pixels, it can be said that the sector is highly concentrated. Index Change 2005-2012 is presented in Figure 2.

By the year 2005, because of the development of market, market concentration declined, but for the period from 2005 to 2006 increased again. During this period, banking system development was driven by favorable macro-economic environment, because of which demand for loans has been growing as well. High concentration of market shows that core banking assets and activity was concentrated in the most important and largest banks in the system. Concentrations increased in 2005-2006, as well as due to differences in the banking situation. Major sector banks were funded by parent banks. Parent banks developed customer service network and that's why country's major banks have been able to offer to their customers relatively cheaper services (Lietuvos bankas, Finansinio stabilumo apžvalga 2005).

From year 2006 to 2010, concentrations of Lithuanian banking sector declined again. During the year of 2006-2007 banking sector has grown rapidly, especially active was credited private sector. Compared with the previous year, the concentration decreased. According to the Bank of Lithuania 2008 financial report, major banks have increased concerns about economic growth prospects, reduced their level of activity and slowed development. Three of largest banks market share fell by 2 percent and the HHI index fell 117 points - from 1888 to the 1771 . During the year 2008-2009 country's economy slowed down, further increased the uncertainty for the future, so banks have stopped their further development. Concentration on these grounds remained similar to 2008. In the first quarter of 2009 three largest banks in the asset's market share dropped to 66 percent. HHI index of 2009 in estate market fell slightly. However, loan market concentration decline was more noticeable.

Concentration of loans in the market decreased from 1930 to 1826 points. In year 2010 the lowest value of the HHI concentration index was recorded - 1605. 2008 crisis contributed to a decrease in concentration in banking sector.

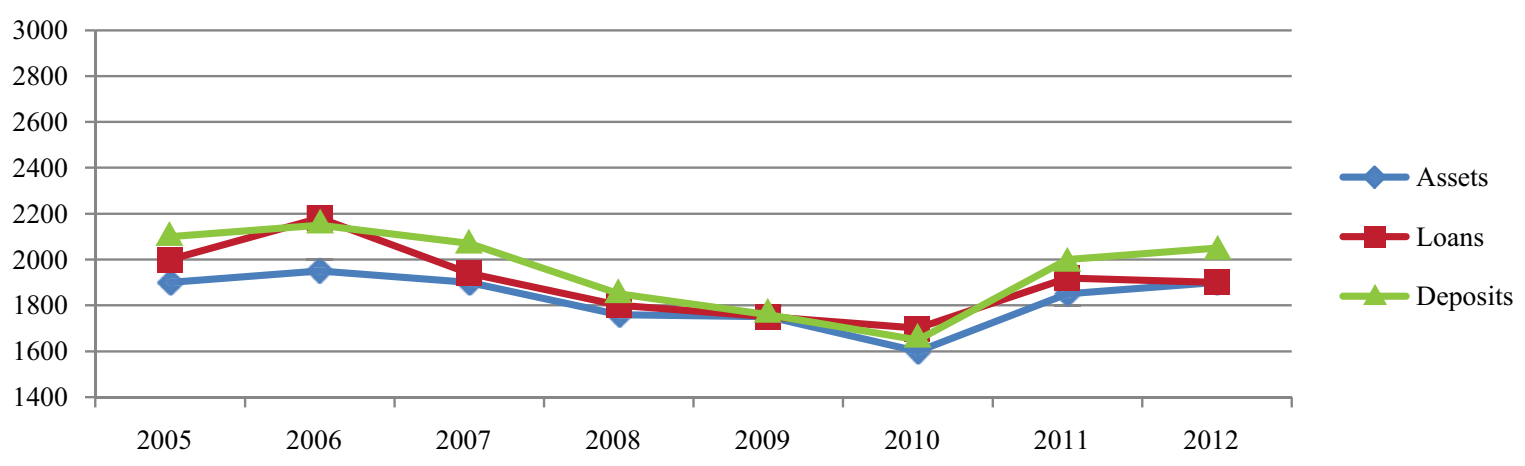

Fig. 2. Change of HHI index in Lithuania (2005-2012)

(Source: Created by authors, according to Lithuanian Bank data) 
During this period, volume of lending has been decreasing dramatically, in major and smaller banks it fell by a similar amount - about 14 percent. Banks applied stricter lending policies as well as reduced the volume of loans and reduced the need for them, as economic recession has affected businesses and households. From the year 2011 to 2012 concentration in Lithuania started to grow again. The market once again became highly concentrated. This was mainly influenced by AB bank Snoras bankruptcy.

Lithuanian banking sector is characterized by the dominant activity of three banks. Under the Law on Competition of the Republic of Lithuania states, if not proved differently, it is considered, that each of three or smaller number of subjects, for which largest market share is subjected, and which together form 70 percent or bigger part of the market, are known as having a dominant position.

Concentration which is concentrated in three largest banks is significantly higher than the market shares of one of the largest banks. This proves that the main share of assets and activity goes to three largest banks in Lithuanian banking sector. All three banks are of Scandinavian capital. These banks are: SEB bank, Swedbank and DNB bank. These banks hold the largest market share of all markets: assets, loans and deposits. Evaluating market concentration by market share of three largest banks of Lithuania, it could be stated that concentration problem exist in Lithuanian banking sector, as banks don't exceed the limit of 70 percent in available assets.

Another widely used in market concentration ratio is the " $k$ " concentration ratio. This ratio measures the largest companies' place in market share. Assessing Lithuanian banking sector concentration within the "k" concentration factor was calculated CR3.

In terms of " $\mathrm{k}$ " concentration factor values of the scale, factor of the concentration values that get in the
35-70 percent range indicates moderate concentration. When the " $\mathrm{k}$ " factor is greater than 70 percent - market is characterized by strong concentration. Lithuanian banking sector concentration of the three largest banks market share on the basis of this factor can be assessed as moderate.

In 2005-2006 three largest banks' assets increased in market share. It have been associated with the development of banking sector. Lending in the period of 2005-2006 have been rapidly growing. In 2006 bank Swedbank AB, SEB AB and DNB bankas together took 74 percent of loan market. This means that bank has issued the largest number of loans. In 2006 bank's loan portfolio amounted to $28,385,475$ thousand LTL, and in the remaining eight banks - 10,255,671 thousand LTL. Concentration lending sector from 2006 to 2010 declined. In 2010, three largest banks held 64 percent of total loans. So over a period of four years, the major share of the bank loan market fell 13.5 percent. In period of 2010-2011 three largest banks in the loan market have been increasing. Amount of loans grew during this period, but before the economic downturn, previous level wasn't reached. In 2011 concentration of loans in the market was 69 percent, and in 2012 was slightly lower and amounted to 68 percent (Fig. 3).

\section{Competition in the Baltic banking sector}

One very widely used indicators for the assessment of competition is Lerner index. Lerner index of the banking sector, banking services, compares prices that are subjected to margin (Weill 2011). The index value increase shows a declining competition in the market and vice versa.

When looking at the Lithuanian banking sector, based on the Lerner index competition in the sector from 2001 to 2005 decreased, competitive market situation was weak, but from 2005 to 2010, the competitive situation in the market has improved (Fig. 4). From 2001 to 2005

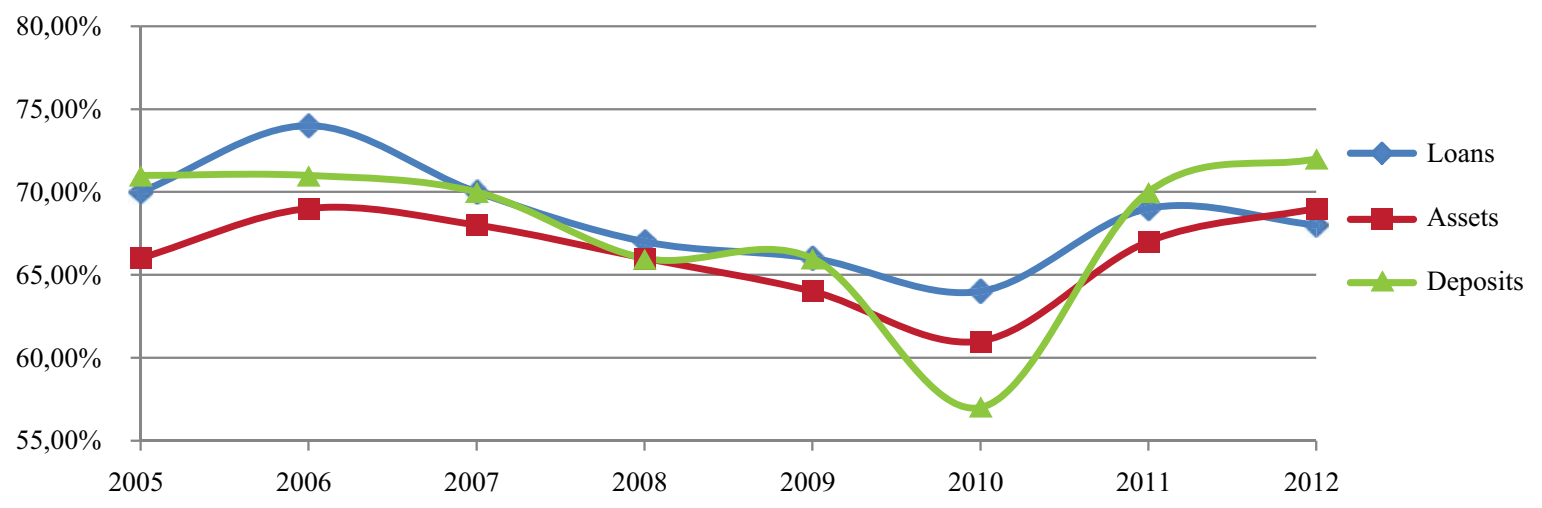

Fig. 3. "K" bank concentration ratio CR3 in 2005-2012

(Source: Created by authors, according to Association of Lithuanian Commercial banks. Indices of bank activities) 


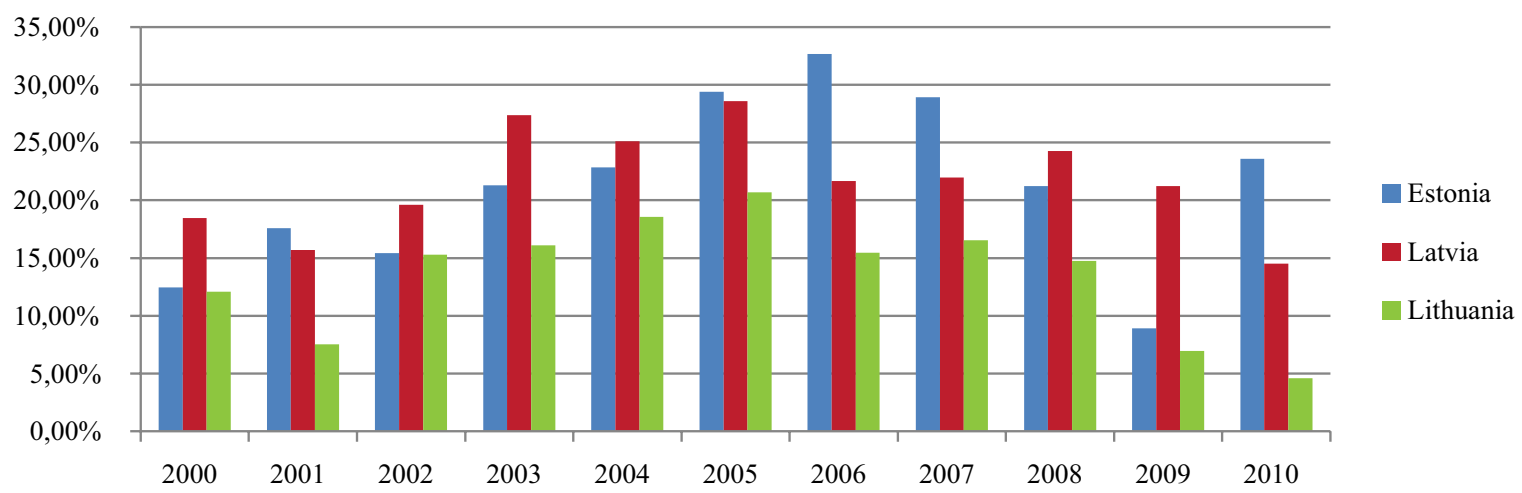

Fig. 4. Lerner index change in the Baltic countries in 2001-2010

(Source: Created by authors, according to World Bank data)

the average Lerner index value in Lithuanian banking sector was 16.89 percent, and from 2005 to $2010-13.17$ percent. This means that the average price in the first period exceeded the marginal costs for 16.89 percent of the amount, and the second -13.17 percent. In other two Baltic states Lerner index reflects greater market power and reduction in the competitive situation between the players in the banking sector. Latvia's biggest Lerner index value is calculated in 2003. At that time, the average price exceeded the marginal costs by almost 30 percent size. The competitive conditions of Latvian banking sector were best in 2006 - the index value was 23.30 percent.

Lerner index value calculated in Estonian banking sector was the highest in 2005 and amounted to 32.66 percent. Market power, based on the assessment of Lerner index, in Estonian banking sector was the lowest in 2008. During this period, average price exceeded marginal costs 8.9 percent, but in 2010 index value has increased again.

Lerner index value in Lithuanian banking sector since 2008 was in a declining trend. However, if looking in the long term, the index value of 2010-2013 period should be clearly higher. The main reasons for that was the liquidation of Snoras bank and Ūkio bankas and increased bank service fees, encouraging electronic banking.

\section{Conclusions}

1. After analyzing the competition of banking sector, it is noted that banking sector competition differs from the competition in other sectors because banks can compete only on the basic banking products. Also, banks are dependent on each other - each market participant actions may strongly affect the other market participants. One problem with the bank can influence the growing distrust of the entire banking system.
2. Lithuanian banking sector is subdivided into three groups, the first of the major banks, second-smaller and medium-sized banks, and third-branches of foreign banks. Main sector is concentrated in three largest banking activities. All of these banks are Scandinavian capital and have, compared with other banks, higher capital resources. Better financial opportunities make big banks more competitive in other banks, so for the smaller banks to compete in the market is difficult.

3. It was found that Lithuanian banking sector is characterized by a high degree of concentration. Taking to the concentration the Herfindahl-Hircshman index, it was found in the year 2005-2012 that there is strong concentration in sector. From 2005 to 2012, three major banks own an average 68 percent of assets, loans and deposits market. According to the market share, Lithuanian banking market structure can be attributed to oligopoly.

4. Lerner index showed that the biggest competition prevails in the Lithuanian banking sector was in the period 2005-2010. The average value of the index was about 13 percent, which means that during this period the average price exceeded the marginal costs by 13 percent size.

\section{References}

Bikker, A.; Spierdijk, L. 2009. Measuring and explaining competition in financial sector, Discussion Paper Series 09-01, Tjalling C. Koopmans Research Institute, Netherlands, 12-13.

Bikker, J. A.; Haaf, K. 2007. Measures of competition and concentration in the banking industry: a review of the literature. $314 \mathrm{p}$.

Casu, B.; Girardone, C. Does competition lead to efficiency? The Case of EU Commercial Banks, University of Essex: 7 p. [online], [cited 18 November 2013]. Available from Internet: http://www3.imperial.ac.uk/pls/portallive/docs/1/48187697. . 
Claessens, S.; Leaven, L. 2005. Financial dependence, banking sector competition, and economic growth, Journal of the European Economic Association 3(1): 3-5 [online], [cited 07 November 2013]. Available from Internet: http://www. jstor.org/stable/40004947.

Deltuvaite, V. ir kt. 2007. The impact of concentration on competition and efficiency in the Lithuanian Banking sector. Kaunas. ISSN 1392-2785.

Estonia banking association [online], [cited 15 November 2013]. Available from Internet: http://www.pangaliit.ee/en/banking-information.

Association of Latvian Commercial banks. Indices of bank activities in the $4^{\text {'th }}$ quarter [online], [cited 15 November 2013]. Available from Internet: http://www.bankasoc.lv/en/ statistics/banks/2005_4.html.

Lietuvos bankas. Lietuvos banko 2011 metų ataskaita. 2012. 43 p.

Lietuvos bankas. Informacija apie kredito ir mokejjimo istaigu veiklą bei jų priežiūrą 2011 m. 2012. 2 p. [online], [cited 14 November 2013]. Available from Internet: http://www. lb.lt/informacija_apie_kredito_ir_mokejimo_istaigu_veikla_bei_ju_prieziura_2011_m

Lietuvos Respublikos konkurencijos įstatymas [online], [cited 05 November 2013]. Available from Internet: http://www3. 1rs.lt/pls/inter3/oldsearch.preps2?Condition $1=111197 \&$ Condition $2=$.

Mcnulty, P. J. 1968. Economic theory and meaning of competition, The Quaterly Journal of Economics, 644.

Pasaulio bankas. Duomenų bazè [online], [cited 15 November 2013]. Available from Internet: http://data.worldbank.org/ data-catalog/global-financial-development.

Staroselskaja, J. 2013. Konkurencija Lietuvos komerciniu banku sektoriuje ir banko pasirinkima lemiančiu veiksniu analizé: daktaro disertacija: socialiniai mokslai, ekonomika (04S). Vilnius: Vilniaus universitetas.

Stigler, G. J. 1972. Economic competition and politic competition [online], [cited 19 November 2013]. Available from Internet: http://www.jstor.org/stable/30022685.

Strahan, P. E. 2002. The real effects of U.S. Banking Deregulation: 14 p. [online], [cited 16 November 2013]. Available from Internet: http://research.stlouisfed.org/conferences/policyconf/papers/Strahan.pdf.

The World Bank Research: Competition in the Financial Sector: Overview of Competition Policies. 2009. 89 p. [online]. Available from Internet: https://openknowledge. worldbank.org/bitstream/handle/10986/4425/wbro_24_1_83. pdf? sequence $=1$

Weill, L. 2011. Bank competition in the EU: How has it evolved? $6 \mathrm{p}$. [online], [cited 17 November 2013]. Available from Internet: http://ifs.u-strasbg.fr/large/publications/2011/2011-04.pdf

\section{KONKURENCIJOS LIETUVOS BANKININKYSTĖS SEKTORIUJE VERTINIMAS}

\section{S. Rimavičiūtè, M. Vilys}

Santrauka

Globalizacija, bankų konsolidacija, pasaulinė finansų krizė pastaraisiais dešimtmečiais stipriai paveikè bankininkystès sektorių. Visi šie pokyčiai turèjo įtakos ir sektoriaus konkurencijai bei kon- centracijai. Bankininkystès sektoriaus konkurencija ir koncentracija nagrinejama teoriniu ir praktiniu aspektais. Analizuojama sąsajos tarp konkurencijos ir stabilumo, efektyvumo bei finansinių paslaugų prieinamumo. Išskiriami pagrindiniai veiksniai, lemiantys konkurenciją bankininkystès sektoriuje. Atlikta Lietuvos bankininkystès sektoriaus analizè, ivvertintas konkurencijos ir koncentracijos Baltijos šalių bankiniuose sektoriuose laipsnis.

Reikšminiai žodžiai: konkurencija, bankininkystès sektorius, koncentracija, ,k“ indeksas, Hiršmano (HHI) indeksas. 